\title{
Correction
}

\section{Anti-ganglioside antibodies in idiopathic and hereditary cerebellar degeneration}

In the article "Anti-ganglioside antibodies in idiopathic and hereditary cerebellar degeneration" (Neurology 2003;60:1672-1673) by Shill et al., Dr. K.O. Bushara's name was inadvertently omitted as an author of this manuscript. The author list should be as follows:

Shill HA, Alaedini A, Bushara KO, Latov N, Hallett M.

The authors regret the error. 


\section{Neurology}

\section{Anti-ganglioside antibodies in idiopathic and hereditary cerebellar degeneration \\ Neurology 2004;62;528 \\ DOI 10.1212/WNL.62.3.528}

\section{This information is current as of February 9, 2004}

\section{Updated Information \&}

Services

Permissions \& Licensing

Reprints including high resolution figures, can be found at: http://n.neurology.org/content/62/3/528.full

Information about reproducing this article in parts (figures,tables) or in its entirety can be found online at:

http://www.neurology.org/about/about_the_journal\#permissions

Information about ordering reprints can be found online:

http://n.neurology.org/subscribers/advertise

Neurology $®$ is the official journal of the American Academy of Neurology. Published continuously since 1951, it is now a weekly with 48 issues per year. Copyright . All rights reserved. Print ISSN: 0028-3878. Online ISSN: 1526-632X.

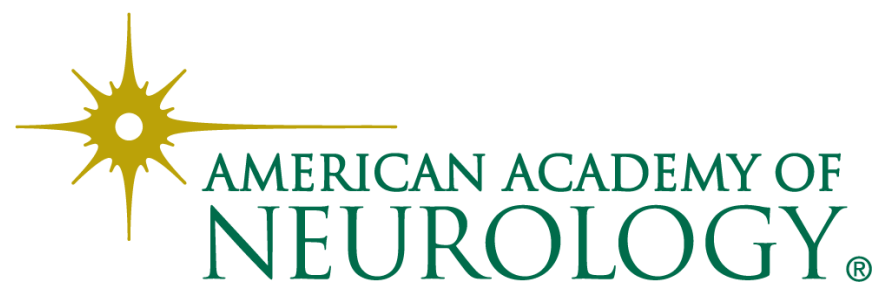

